\title{
Meteorite Craters
}

\section{By Dr. L. J. SPEncer, F.R.S.}

$\mathrm{T}$ HE famous Meteor Crater near Cañon Diablo in Arizona (Fig. 1) is now generally believed to have been formed by the impact of a gigantic meteorite, though it still remains a subject for discussion. A good account of the crater was given by the late Sir Lazarus Fletcher in NATURE in 1906 (vol. 74, pp. 490-492). It is a cup-shaped depression measuring three-quarters of a mile across and with a depth of 570 feet. The rim rises gently from the surrounding desert plain to a height of 130 to 160 feet, and is strewn with huge blocks of sandstone and limestone and much fine debris. The strata exposed in the inner walls dip radially outwards from the centre, while in the surrounding country the bedding is horizontal. Around the crater, within a radius of six miles, thousands of masses of metallic nickel-iron (containing nickel, $7 \cdot 33$ per cent) have been collected since the first discovery in 1891. The masses found range in weight from a fraction of an ounce to 460 kilos (1014 lb.). Estimates of the total amount gathered up range from six to twenty tons. Nearly four tons of this material are preserved in the larger meteorite collections of the world. Some of the masses are surrounded by a crust of laminated 'iron-shale', which has evidently been formed by the rusting of the iron; and fragments of such material are found in abundance. Inside the crater only four smaller masses have been found, but there are indications of the 'iron-shale'.

A point of special interest about these Cañon Diablo irons is the presence in some of the masses of small diamonds, both black and white; and it was doubtless this observation that suggested to H. Moissan his experiments on the artificial production of diamond. Moissan also detected in the iron the presence of native carborundum (silicon carbide), which as a meteoric mineral has been named moissanite. Other rarer constituents of this meteoric iron are platinum metals. One assay yielded platinum 3.65 and iridium 14.95 grams per metric ton, but some other later trials gave negative results.

The view that the crater was formed by the impact of a gigantic meteorite, perhaps 500 feet in diameter and weighing more than a million tons, led to the belief that such a mass would be found buried in the crater and would well repay mining operations. Mining claims were taken out and several trial borings were put down in the centre of the crater. In the bore-holes undisturbed rock was met at depths of about 650 feet, but nothing of value was found-only traces of oxidised iron and nickel. Another bore-hole was put down several years later under the southern wall of the crater, on the supposition that the meteorite had entered at a slanting angle; but again without any decisive result. After passing through 30 feet of iron-shale cementing fragments of metamorphosed sandstone, the drill stuck, at a depth of 1376 feet, presumably against some hard object, which was thought to be perhaps the main mass of the meteorite. In these borings there was encountered a large amount of 'rock-flour', consisting of crushed grains of quartz from the sandstone ; and, in places, some pumice-like material, consisting of silica-glass, which was no doubt formed by the fusion of the sandstone.

In this region there are no volcanic rocks and no indications of volcanic or solfataric activity, so

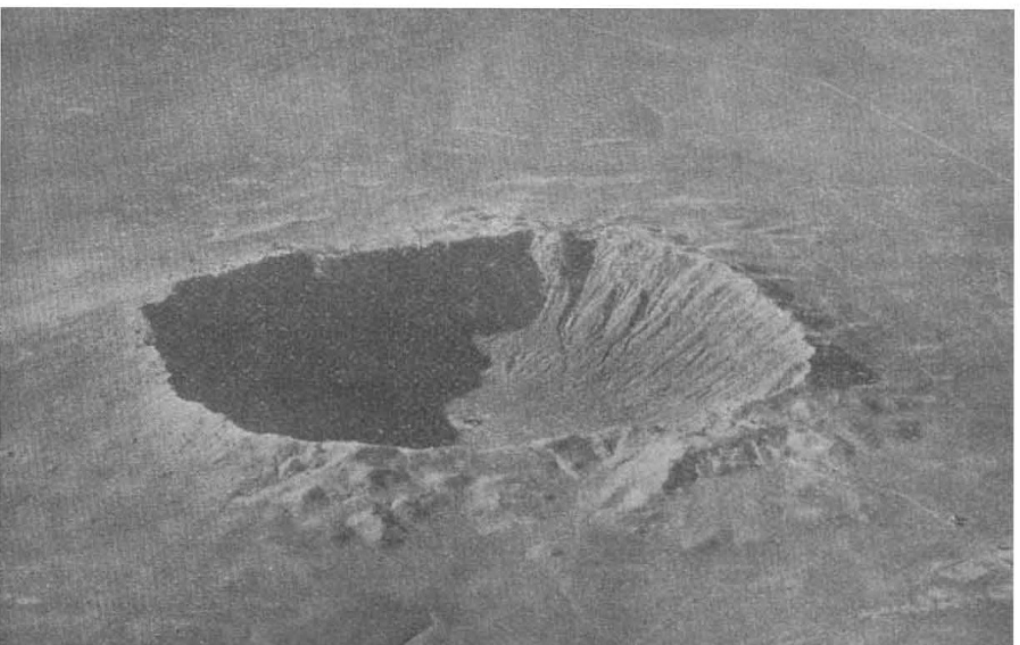

FIG. 1.-Meteor Crater, near Cañon Diablo, Arizona. Air photograph from north-west of the crater, almost in the direction and angle at which the meteorite is supposed to have struck. that a volcanic origin of the crater is ruled out. The idea that it was formed by a steam explosion is, also, not supported by the facts ; and still less a recently expressed opinion that the crater owes its origin to the solution of the limestone and is of the nature of a sink-hole. The intimate intermingling of huge blocks and finely powdered sedimentary rocks with meteoritic material indicates that there must be a close connexion between the fall of a meteorite and the formation of the crater; and the fusion of the sandstone, giving silica-glass, could no doubt have been effected by the heat generated by the impact of the mass. With the development of a temperature $\left(1400^{\circ}-1800^{\circ} \mathrm{C}\right.$. $)$ sufficient to fuse quartz, and the presence of water in the surrounding rocks, explosive action from this secondary cause must have helped in making the crater and scattering the fragmentary material. Such a ' back-fire' would explain why the meteorite fragments are found only outside the crater, and it may also be the cause of the upward tilting of the strata in the crater-walls. 
A small meteoric stone entering the earth's atmosphere with planetary velocity (up to 45 miles per second) is quickly checked by the resistance of the air, and it reaches the earth's surface with the velocity of an ordinary falling body of about 70 metres per second. But with an enormous mass of metal travelling at such a velocity the momentum is much greater, and it would be difficult to conceive what would be the actual state of affairs (any unfortunate observer would have no opportunity of recording his observations). Meteorites with the surrounding ground, and around it there is no sign of a crater.

Until quite recently the crater in Arizona was the only known example of this type of feature on the earth's surface-a feature which, though on a much smaller scale, has been compared with the craters of the moon. In 1921 a mass of meteoric iron was found near Odessa in Ector Co., Texas, and since then it has been noticed that the spot is marked by a crater. This is roughly circular in outline, with an average diameter of 530 feet. The

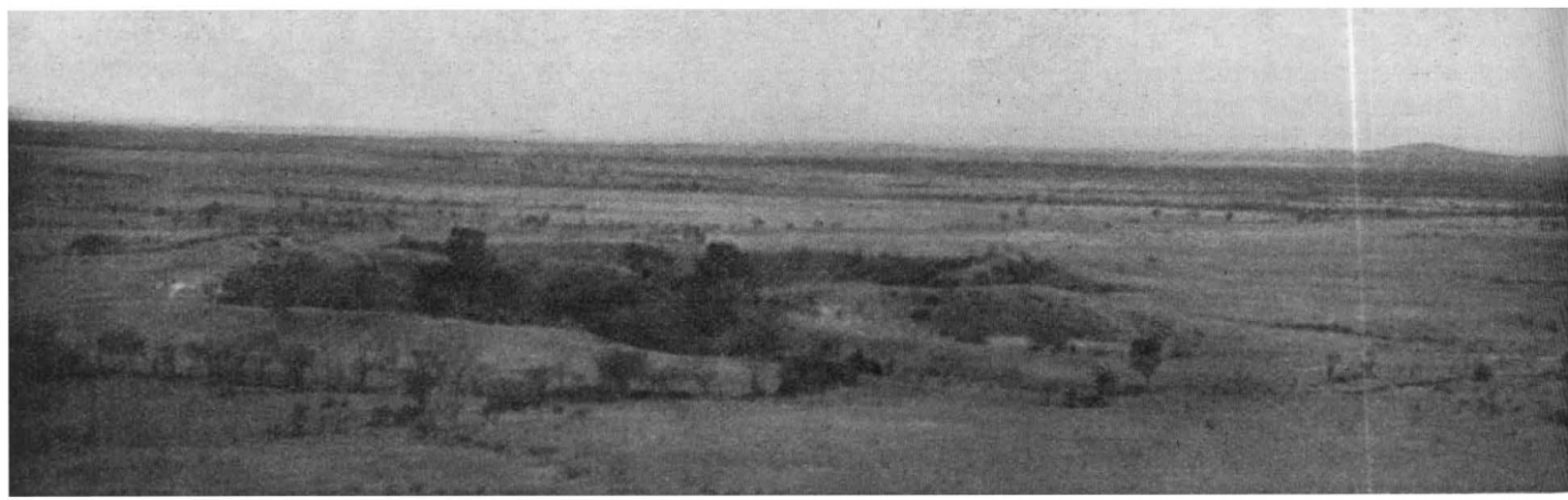

FIG. 2.

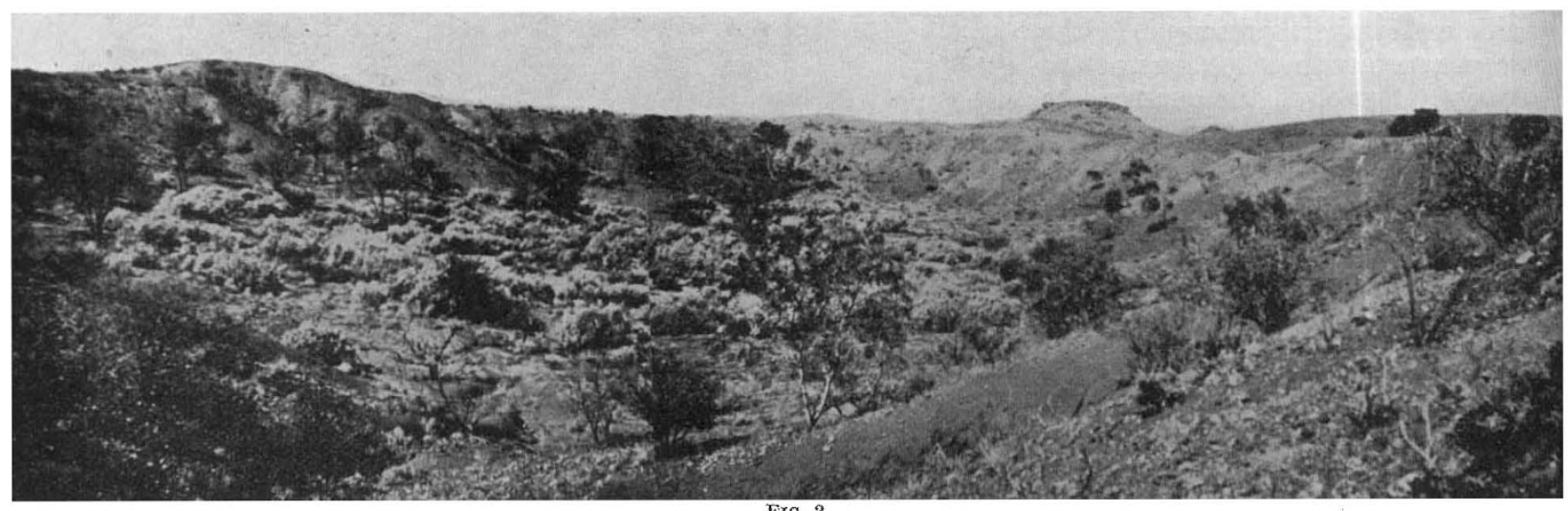

FrG. 3.

Meteorite Craters at Henbury, Central Australia *

Frg. 2.- View from the south of craters Nos. 6, 7 , and 8. The larger trees are in the 'Water Crater' (No. 6). Fic. 3.- Panoramic view of the 'Main Crater' (No. 7 ).

actually observed to fall have made holes in the ground usually not more than one or two feet in depth. The largest meteorite of which the fall has been observed is a stone of $820 \mathrm{lb}$. which fell at Paragould in Arkansas on Feb. 17, 1930. This penetrated clayey soil to a depth of 8 feet, scattering clods to a distance of 50 feet in the pasture. A stone of 293 kilos (645 lb.) which fell at Knyahinya in Czechoslovakia on June 9, 1866, penetrated to a depth of 11 feet. On the other hand, the largest known meteorites, all of which are irons not observed to fall, have been found by reason of them being partly exposed at the surface of the ground. The 60-ton Hoba meteorite discovered in SouthWest Africa in 1920 has its upper surface level

* Figs. 2-5 are taken from Mr. A. R. Alderman's paper on the Henbury craters, published in the Mineralogical Magazine, March 1932, vol. 23, pp. 19-32. rim is about 18 feet above the bottom of the hole, but only 2 or 3 feet above the surrounding desert plain, where horizontally bedded limestone is exposed. The steep inner slopes show the limestone dipping at $20^{\circ}-30^{\circ}$ away from the centre. Numerous pieces of "iron-shale" and a few small pieces of metal have been found on the surface of the rim. The various suggested modes of origin of this crater that have been discussed include: (1) volcanic explosion ; (2) salt dome ; (3) expansion by hydration of anhydrite ; (4) explosion of gas ; (5) fall of a meteorite.

A group of similar but smaller craters on the island of Oesel (Esthonia) in the Baltic has recently been surveyed in detail and borings made. The main crater, in which there is a small lake, is 110 metres across and its rim is 6 metres above the 
surrounding ground, while inside the depth is $50-60$ metres. On the inside walls the beds of dolomite rock dip away from the centre, and there is a zone of pulverised rock. Six other small craters, 14-39 m.

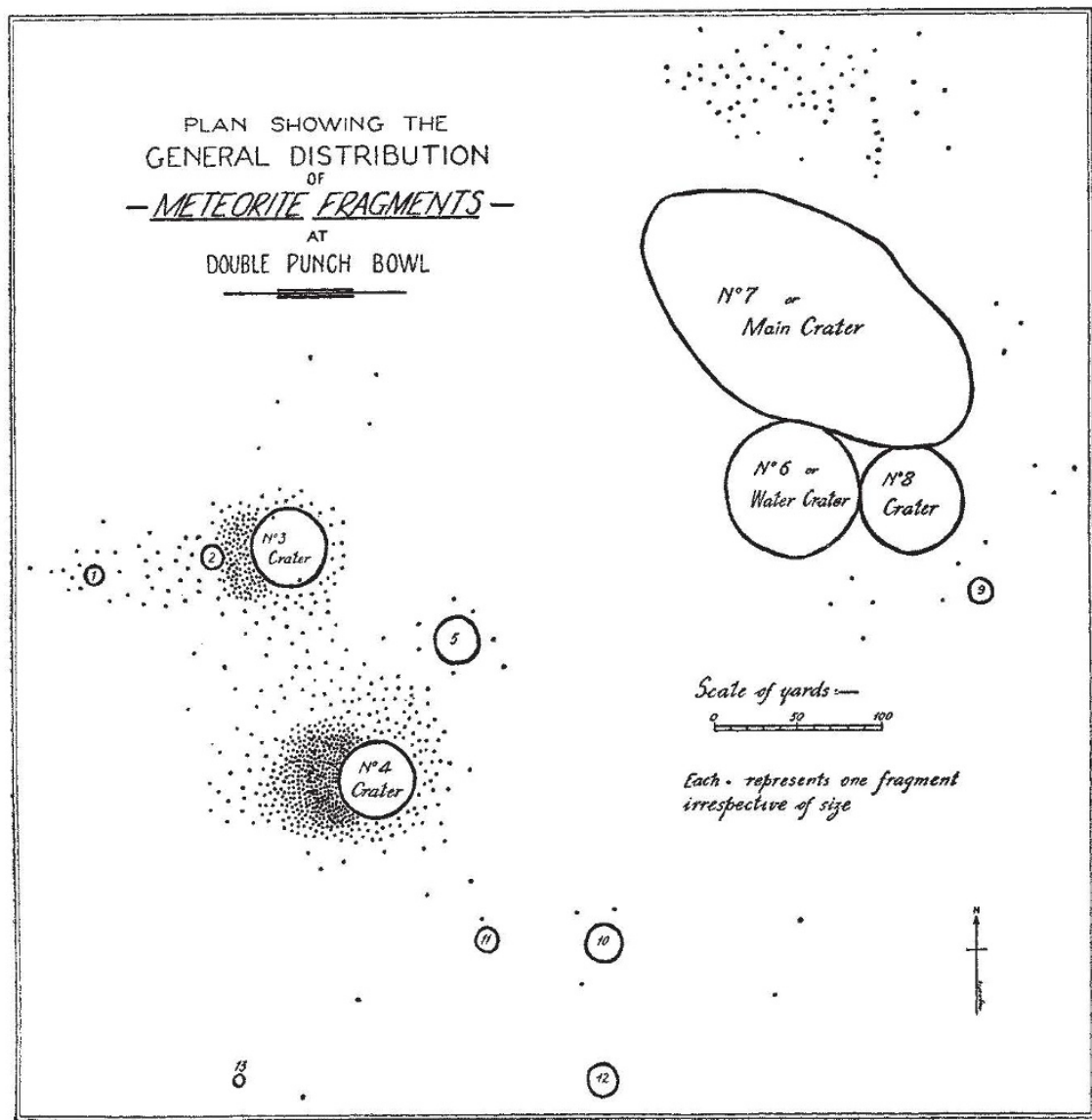

FIG. 4,-Plan showing the general distribution of the craters and of the meteorite fragments around them at Henbury Central Australia. radially outwards over a radius of 60 kilometres. In the centre of the devastated area was discovered a group of ten craters, with diameters of 10-50 metres and a mean depth of 4 metres. Boring inside the craters to a depth of 10 metres in the frozen ground yielded no meteorites.

In the instances briefly described above we have two cases of single craters associated with meteoritic material and two cases of groups of craters without meteoritic material. A more recent discovery is that near Henbury, about 50 miles south of the MacDonnell Ranges, in the very centre of Australia. Here a group of thirteen craters is associated with abundant meteoritic material, and the evidence of a connexion between the two is much more conclusive. The locality was visited in May 1931 by Mr. A. R. Alderman, of the University of Adelaide, and his description of the craters is published in the March issue of the Mineralogical Magazine. Eight hundred pieces of meteoric iron were then collected. In June 1931, a visit was made by Mr. R. Bedford, of the Kyancutta Museum,

across, are in the vicinity. Suggested origins that have been considered in this case are: (1) artificial earthworks; (2) gas explosion; (3) oozing out of a bed of clay; (4) Karst weathering of the dolomite ; (5) expansion of salt or anhydrite; (6) fall of a meteorite. In this case no trace of meteoritic material was found, but in spite of this, a meteoric origin of the craters has been thought probable.

The great Siberian meteor of June 30, 1908, left its mark in a series of craters in the ground, but no meteoritic material has been found. Expeditions to the inhospitable region on the Stony Tunguska river in central Siberia were led to the spot by the devastation of the pines, forest trees being felled

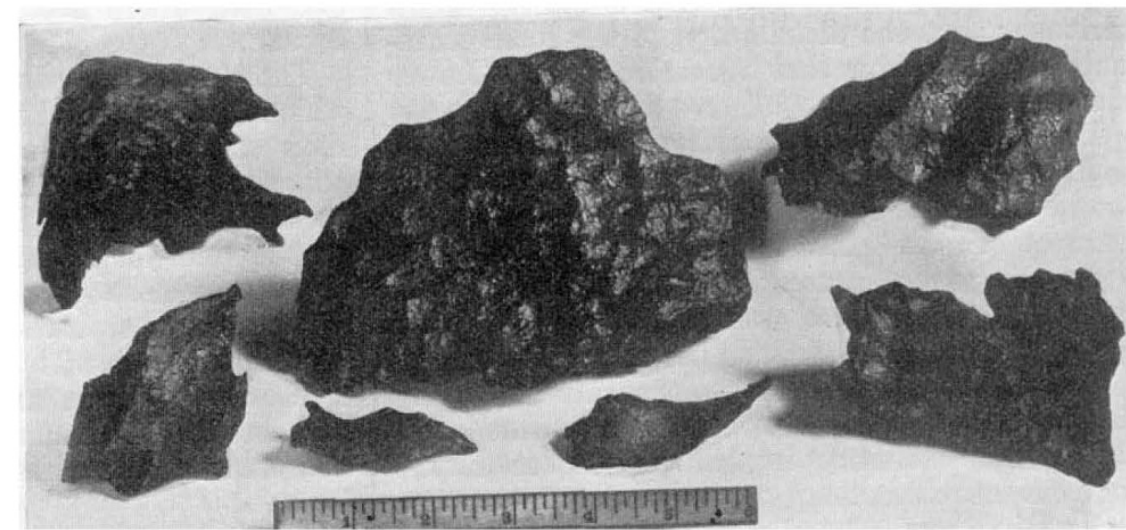

FIG. 5.--Typical fragments of meteoric iron from the meteorite craters at Henbury, Central Australia (with scale of inches).

No. 3265, VoL. 129]

South Australia, who has sent 542 pieces of the iron, together with fragments of 'iron-shale' and scoriaceous silica-glass, to the British Museum (Natural History). A selection of Mr. Bedford's material is now exhibited on loan in the Mineral Gallery of the Natural History Museum at South Kensington. 
The Henbury craters show an irregular distribution within an area of half a mile square. The three larger ones are adjacent, and the largest measures 220 by 120 yards across, with a depth of 50 to 60 feet. The others are approximately circular in outline, with diameters ranging from 10 to 80 yards. Owing to the craters acting as collecting pans for rain-water in this arid region, the spots are marked by the growth of mulga trees, acacias, and coarse grass. This helps to locate the craters, which with their gently sloping outer surfaces are not very conspicuous until the interior is viewed from the edge of the rim. Radiating outwards from some of the craters into the plain are five or six low ridges of sandstone, which may have some relation to the percussion of the meteorites. The steep inner walls of the craters consist of powdered rock and shattered blocks of sandstone, quartzite, and slate. The masses of iron found scattered around these craters range from a fraction of an ounce to $170 \frac{1}{2} \mathrm{lb}$. in weight. In one area of 6 feet by 6 feet more than a hundred pieces were collected. Many of the smaller pieces are flaky and shell-like, and are probably the result of the breaking down of larger masses by weathering. Laminated 'ironshale ${ }^{3}$ in pieces up to several pounds in weight has been found in association with the irons, and it is evident that this has resulted by oxidation of the iron. As at the Meteor Crater in Arizona, it is remarkable that very little meteoritic material has been found within the crater-walls. Here only two pieces of iron have been found inside one of the craters; and in one of the smaller craters a borehole through fine silt down to coarse rock fragments at a depth of 8 feet yielded no mass of iron. Outside the craters were found some fragments of scoriaceous glassy material, which in micro-sections is seen to consist of silica-glass impregnated with iron oxide. This resembles the Arizona material, and was no doubt formed by the fusion of the sandstone by the impact of the meteorite.

At Henbury, with the numerous masses of iron scattered around several craters, there must have been not a single meteorite, but a shower. Further exploration of the locality is to be made this year, and it is hoped that more data will then be available. In the meantime any speculation on the mechanics of the formation of such craters must involve many assumptions. Mr. Alderman is of the opinion that the craters were formed ages ago, while $\mathrm{Mr}$. Bedford believes that they are comparatively recent. The latter mentions that the old blacks will not camp near the place, and that they call it " chindu chinna waru chingi yabu", meaning "sun walk fire devil rock" ; which suggests that the natives have some tradition of the fall.

\section{Implements of Chinese Fossil Man}

$\mathrm{T}$ HE scientific reports on the discovery of implements and remains of fires in association with the fossil man Sinanthropus have now been published by the Geological Society of China.* It is therefore possible to appreciate the significance of this addition to our knowledge of one of the earliest representatives of the human race. There are no traces of glacial or pluvial episodes in the superficial deposits of eastern China to mark horizons; but the distribution of the fossil mam. mals seems to show that Sinanthropus is of Lower Pleistocene age. $t$

The disintegrated charcoal from wood fires occurs abundantly in old hearths resembling those which are now familiar in the Palæolithic settlements of Europe. In one place it is scattered throughout a deposit seven metres thick, and Prof. Breuil remarks that the fire was probably replenished continuously during the long period which is represented by so great a thickness of residue. Among the charred remains are numerous burnt bones and stones, including implements. Deer antlers were cut into short lengths by flakes of stone, aided by burning at the lines of section. The bases of antlers seem to have been used as hammers. The

* D. Black, "Evidences of the Use of Fire by Sinanthropus", Bull Geol. Soc. China, vol. 11, pp. 107, 108; 1931. H. Breuil, "Le Feu et I'Industrie Lithique et Osseuse a Choukoutien", tom. cit., pp. 147-154 (also in L'Anthropologie, vol. 42, pp. 1-17; 1932). W. C. Pei, "Notice of the Discovery of Quartz and other Stone Artifacts in the Lower Pleistocene Hominid-bearing Sediments of the Choukoutien Cave Deposit", tom. cit., pp. 109-139, pls. i-iii.

Deposit", tom. cit., pp. 109-139, pls. i-iii. Geol. Soc. China, vol. 10, pp. 165-178; 1931. C. C. Young, "Die Stratigraphische und Palaeontologische Bedeutung der fossilen Nagetiere Chinas", tom. cit., pp. 159-164, with 3 tables.

No. 3265 , VoL. 129$]$ young antler fixed to a piece of skull was used whole, the base being trimmed for a convenient handle. Bits of brain-case seem to have been made into cups ; some of the upper jaws were evidently used as files, and some of the lower jaws as small picks, with the coronoid process as working tip. The long bones were regularly broken for the marrow, and some of them seem to have lost only one end, where a stone would be fixed as in a handle.

The stone implements are rudely made of flakes which have been taken from stones found in the river below, and from quartz which occurs on the opposite side of the valley. They are well described by $\mathrm{Mr}$. Pei, and are illustrated with both photographs and diagrams. They are all small, the largest not more than $15 \mathrm{~cm}$. in greatest diameter, and they are at least as varied in shape as the implements met with in the Mousterian deposits of Europe. There are cores and flakes, showing that the implements were made on the spot, and some of the cores themselves are retouched for use.

As the Choukoutien deposits obviously represent a human dwelling-place, while the only remains of Sinanthropus hitherto discovered in them are skulls and jaws, Prof. Breuil discusses the suggested possibility, that the fires and implements were made by a higher type of man who collected the skulls of a lower race as trophies of the hunt. He wisely rejects this suggestion, and looks forward to the discovery of numerous still more primitive ancestral men with real human intelligence. 